\title{
DÜBLIN
}

Technological University Dublin

ARROW@TU Dublin

\section{Solar Photovoltaic Water Pumping for Multiple Use Systems (MUS) in Nepal}

\author{
Fintan McLoughlin \\ Technological University Dublin, fintan.mcloughlin@tudublin.ie \\ Aidan Duffy \\ Technological University Dublin, aidan.duffy@tudublin.ie \\ Michael Conlon \\ Technological University Dublin, michael.conlon@tudublin.ie
}

Follow this and additional works at: https://arrow.tudublin.ie/dubencon2

Part of the Electrical and Electronics Commons, and the Power and Energy Commons

\section{Recommended Citation \\ McLoughlin F., Duffy, A. \& Conlon, M. (2013). Solar photovoltaic water pumping for Multiple Use Systems (MUS) in Nepal. 48th International Universities' Power Engineering Conference (UPEC), Dublin, Ireland, 2- 5,September, 2013}

This Conference Paper is brought to you for free and open access by the Dublin Energy Lab at ARROW@TU Dublin. It has been accepted for inclusion in Conference Papers by an authorized administrator of ARROW@TU Dublin. For more information, please contact arrow.admin@tudublin.ie, aisling.coyne@tudublin.ie, gerard.connolly@tudublin.ie. Funder: DIT Foundation 


\section{Solar photovoltaic water pumping for Multiple Use Systems (MUS) in Nepal}

\author{
Dr. Fintan McLoughlin \\ Dublin Energy Lab \\ Dublin Institute of Technology \\ fintan.mcloughlin@dit.ie
}

\author{
Dr. Aidan Duffy \\ Dublin Energy Lab \\ Dublin Institute of Technology \\ aidan.duffy@dit.ie
}

\author{
Dr. Michael Conlon \\ Dublin Energy Lab \\ Dublin Institute of Technology \\ michael.conlon@dit.ie
}

\begin{abstract}
This paper investigates the performance of five solar photovoltaic (PV) Multiple Use Systems (MUS) used for water pumping. The solar MUS's provide water for drinking, cleaning and micro-irrigation for some of the poorest communities in Nepal. In the absence of data logging, the performance of each system is investigated based on a series of rules of thumb to determine the predicted, expected and estimated demand and supply of water to small rural communities. The systems are compared based on their technical and economic performance and how this relates to local environmental, physical and socioeconomic characteristics at each location.
\end{abstract}

Index Terms-Solar photovoltaic, water pumping, international development, Nepal

\section{INTRODUCTION}

Nepal has a unique geographic terrain with steep valleys which make it difficult to retain water. This is most apparent in the most marginalized communities which are generally located within the hills and mountainous regions. Due to local weather patterns throughout the year, it is often the case communities only receive adequate rainfall for three months of the year during monsoon season (June - August). The rest of the time community members have to source water by other means such as manually collecting or pumping water from nearby sources.

Alternative methods to manual collection include gravity fed systems and water pumping. Gravity fed MUS's are somewhat reliant on the physical geography for their successful operation. These systems use gravity to collect water and therefore location of the water source relative to the community is critical in their design. Where gravity MUS are not viable, water pumping is required to replace manual collection. For shallow wells $(<7$ metres) Treadle (foot) pumps are used. However, where pumping height is significantly higher electricity, liquid fuels (diesel or kerosene) and renewable energy powered pumps are usually used to lift water from a source. Table I summarises the major advantages and disadvantages to each water collection method.

The use of PV and their suitability to water pumping has increased over the last decade. This is mostly due to
TABLE I

ADVANTAGES AND DISADVANTAGES TO WATER COLLECTION METHODS

\begin{tabular}{|l|l|l|}
\hline Method & Advantages & Disadvantages \\
\hline Manual \& Treadle & little or no capital costs & labor intensive \\
\hline Gravity & low operating cost & site specific \\
\hline Electricity & $\begin{array}{l}\text { low upfront capital } \\
\text { costs }\end{array}$ & $\begin{array}{l}\text { unreliable due to load } \\
\text { shedding }\end{array}$ \\
\hline Liquid fuels & $\begin{array}{l}\text { low upfront capital } \\
\text { cost }\end{array}$ & high operating costs \\
\hline Renewable energy & low operating costs & $\begin{array}{l}\text { high upfront capital } \\
\text { costs }\end{array}$ \\
\hline
\end{tabular}

decreasing infrastructure costs where in recent years the levelized cost of electricity has reached grid parity in many locations around the world [1]. In addition, various authors have concluded that over the project lifetime (usually 20 years) solar can often be more economic to alternative methods such as diesel pumping, particularly in off-grid applications [2][3][4]. However in spite of this, significant challenges still exist with these technologies not least around the operation and maintenance of such systems in developing countries [5].

It is the purpose of this paper to give an overview of the technology used and the system performance in order to ascertain whether community demand for water is being met by the installations. A comparative analysis as to the impact of local environmental, physical and socio-economic variables on the system performance is also assessed. As a result it will be possible to make better informed decisions as to suitable locations and designs for similar projects in the future. A life cycle analysis was not carried out as data was not available on the O\&M costs.

\section{METHODOLOGY}

Fig. 1 shows the location for each solar MUS installation. The locations were chosen based on a number of different factors such as: proximity to a nearby water source, lift height, community access and general enthusiasm within the community for such an installation. Kavre and Kaski were commissioned in early 2013 with the remaining installations taking place in April 2013. 


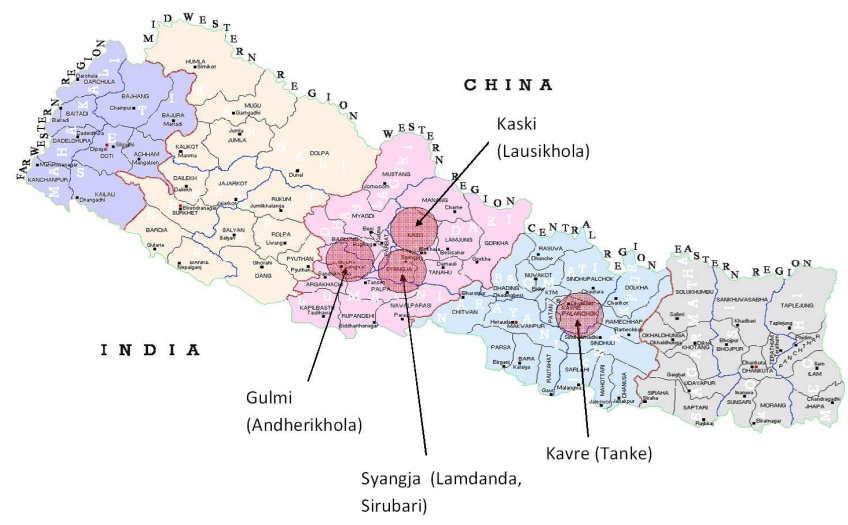

Fig. 1. Solar MUS project locations: Kavre $\left(27^{\circ} 37^{\prime}-83^{\circ} 35^{\prime}\right)$; Sirubari $\left(28^{\circ} 05^{\prime}-83^{\circ} 52^{\prime}\right)$; Lamdanda $\left(28^{\circ} 05^{\prime}-83^{\circ} 52^{\prime}\right)$; Gulmi $\left(28^{\circ} 05^{\prime}-83^{\circ} 18^{\prime}\right)$; Kaski $\left(28^{\circ} 16^{\prime}-83^{\circ} 53^{\prime}\right)$.

The amount of water which can be pumped on a daily basis is highly dependent on the level of solar radiation available at a site as well as other factors such as lift height and flow rate. Fig. 2 shows typical daily average solar radiation at each location across the year. As Sirubari, Lamdanda, Gulmi and Kaski were all located in close proximity they all receive a similar solar radiation. However, as Kavre is located further south it receives slightly more solar radiation during the winter and less in the summer months (monsoon season).

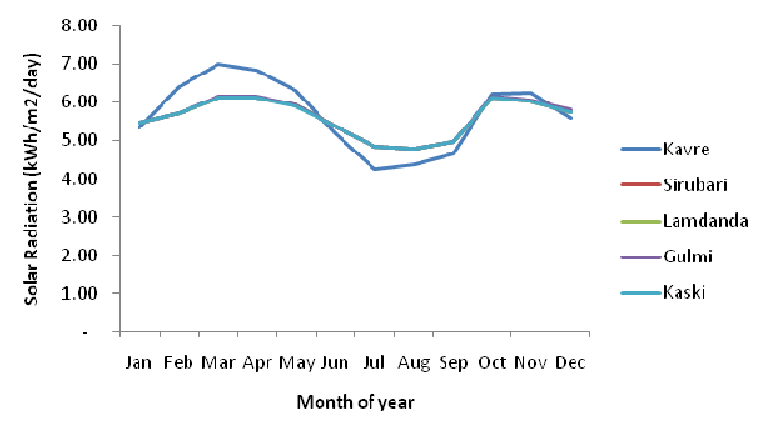

Fig. 2. Solar radiation for each solar MUS location

Equation (1) shows the general relationship for the amount of energy (power in watts) needed to pump water where $\eta$ is the efficiency of the system, Q is the flow rate $\left(\mathrm{m}^{3} / \mathrm{s}\right), \rho$ is the density of water $\left(\mathrm{kg} / \mathrm{m}^{3}\right)$, g is gravity $\left(9.81 \mathrm{~m}^{2} / \mathrm{s}\right)$ and $\mathrm{H}$ is the lift height (metres).

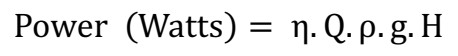

Equation (1) shows that for a constant supply of power, there is an inverse relationship between the lift height and flow rate. Therefore as the lift increases, the flow rate decreases, resulting in less water being pumped. The distance between the source and community tanks, as well as the pipe diameter are important parameters as these dictate the level of frictional losses associated with pumping water. Similarly, the distance between the solar panels and pump will determine the electrical losses associated with the cables. Each of these parameters is shown in Table II for each installation. A constant transmission pipe diameter of $40 \mathrm{~mm}$ was used at each site.

TABLE II

TECHNICAL DESIGN PARAMETERS FOR EACH SOLAR MUS INSTALLATION

\begin{tabular}{|l|l|l|l|}
\hline Location & Lift height (m) & $\begin{array}{l}\text { Distance PV } \\
\text { panel to pump } \\
(\mathbf{m})\end{array}$ & $\begin{array}{l}\text { Distance source } \\
\text { to community } \\
\text { tank (m) }\end{array}$ \\
\hline Kavre & 170 & 240 \\
\hline Sirubari & 81 & 90 & 291 \\
\hline Lamdanda & 51 & 100 & 217 \\
\hline Gulmi & 77 & 190 & 300 \\
\hline Kaski & 80 & 70 & 350 \\
\hline
\end{tabular}

Table III shows the number of households and persons as well as the water demand for each community. Predicted water demand is calculated based on the current population for a community and assumes an annual increase of $1.73 \%$ in demand over the project lifetime (20 years). Each community member is assumed to consume 45 litres per day (lpd). In addition, Sirubari and Lamdanda were allocated an additional 2,000 and $400 \mathrm{lpd}$ respectively on account of there being a school within the community. Gulmi was allocated an extra 8,100 litres per day for additional vegetable farming.

TABLE III

SOCIO-ECONOMIC VARIABLES AND WATER DEMAND FOR EACH COMMUNITY

\begin{tabular}{|l|l|l|l|}
\hline Location & $\begin{array}{l}\text { No. } \\
\text { households }\end{array}$ & $\begin{array}{l}\text { Design No. } \\
\text { persons }\end{array}$ & $\begin{array}{l}\text { Predicted water } \\
\text { demand (lpd) }\end{array}$ \\
\hline Kavre & 59 & 316 & 20,250 \\
\hline Sirubari & 32 & 199 & 12,890 \\
\hline Lamdanda & 70 & 440 & 25,560 \\
\hline Gulmi & 26 & 168 & 17,685 \\
\hline Kaski & 46 & 246 & 12,750 \\
\hline
\end{tabular}

Fig. 3 shows the general layout for the solar MUS design. The same design was used at each site and does not change except for equipment ratings. A gravity fed system was used to collect water from a nearby source, which was then stored in a tank. Mono-crystalline PV panels were used to generate electricity which in turn was used to power an alternating current (AC) submersible pump. Water is pumped from the source tank to a tank located above the community. The system is operated under gravity from this point forward with water being released on demand by the community members. In some cases a community caretaker manages the supply of water by turning on and off a valve located at the community storage tank. In addition, water supply can also be restricted by way of a valve located at each tap stand. 


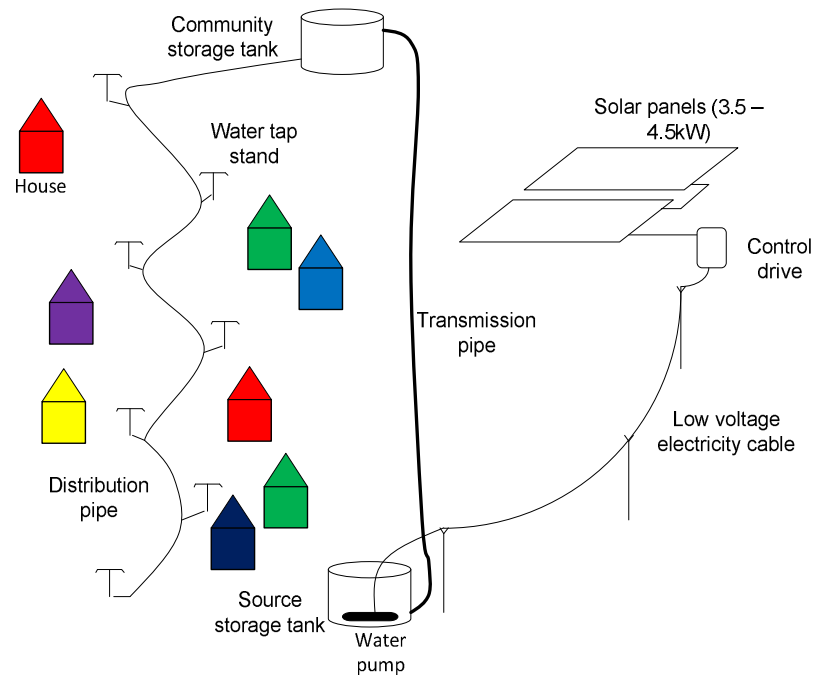

Fig. 3. Solar MUS generic design layout

A control drive connects the solar PV to the AC pump and manages its operation by carrying out the following functions:

1) converts direct current (DC) electricity to alternating current $(A C)$

2) controls the start/stop times for the pump by way of a solar radiation sensor

3) adjusts the flow rate of the pump by changing the Variable Frequency Drive (VFD) to allow for continuous pumping even in low solar radiation conditions

The solar MUS system is controlled via a solar radiation sensor, positioned on top of the solar PV panels. As the solar radiation fluctuates throughout the day the control drive alters the frequency of the pump (i.e. the number of times it rotates and hence the amount of water pumped in one minute). At rated conditions the system will operate at $50 \mathrm{~Hz}$ which means the pump will turn at 3,000 revolutions per minute (rpm). If there is not sufficient solar radiation and hence power available from the PV panels the control drive will switch to a lower frequency. This ensures continuous operation of the pump in low solar radiation conditions. It also means that the whole system will operate for an extended period of time throughout the day compared to installations where a control drive is not installed.

Table IV shows installed solar PV equipment for each solar MUS installation. On all sites except Gulmi an ABB ACS355 controller and a Grundfos SP 3A-25 pump was installed rated at 1500 Watts. A slightly larger control drive and pump (SP 3A-29) rated at 2200 Watts was installed in Gulmi on account of both a large demand for water as well as a high lift and transmission distance within the community.
TABLE IV

INSTALLED PV EQUIPMENT AT EACH LOCATION

\begin{tabular}{|l|l|l|l|c|c|}
\hline Location & Kavre & Sirubari & Lamdanda & Gulmi & Kaski \\
\hline Manufacturer & Sunco & Sunco & Sunco & Sunco & Senerson \\
\hline Model & $\begin{array}{l}\text { SSM } \\
175\end{array}$ & $\begin{array}{l}\text { SSM } \\
60 \mathrm{P}\end{array}$ & $\begin{array}{l}\text { SSM } \\
60 \mathrm{P}\end{array}$ & $\begin{array}{l}\text { SSM } \\
60 \mathrm{P}\end{array}$ & $\begin{array}{l}\text { SSM } \\
72\end{array}$ \\
\hline No. of panels & 18 & 18 & 18 & 18 & 24 \\
\hline Power (Wp) & 170 & 250 & 250 & 250 & 190 \\
\hline $\begin{array}{l}\text { Total power } \\
\text { (Watts) }\end{array}$ & 3060 & 4500 & 4500 & 4500 & 4560 \\
\hline $\mathrm{V}_{\text {OC }}$ (Volts) & 44.00 & 36.30 & 36.30 & 36.30 & 45.05 \\
\hline $\mathrm{I}_{\mathrm{SC}}$ (Amps) & 5.40 & 8.71 & 8.71 & 8.71 & 5.74 \\
\hline $\mathrm{V}_{\mathrm{MPP}}$ (Volts) & 35.60 & 30.60 & 30.60 & 30.60 & 36.5 \\
\hline $\mathrm{I}_{\mathrm{MPP}}$ (Amps) & 4.92 & 8.17 & 8.17 & 8.17 & 5.21 \\
\hline
\end{tabular}

\section{RESULTS}

The following section presents results for each of the solar MUS installations. Fig. 4 shows predicted water demand as well as the quantity of water pumped (supplied) (both expected and estimated) to each community. The expected amount of water pumped to each location was calculated by Sunco using their own software. As data logging was not installed, the quantity of water pumped on a daily basis by each system was estimated by measuring the instantaneous flow rate on three separate occasions under similar solar radiation conditions and taking the average value. The amount of water pumped by each system was then inferred from this average instantaneous value to determine nominal flow rate. The estimated amount of water pumped on a daily basis then assumes a constant nominal flow rate for a period of 6.5 hours during the course of the day, which slightly overestimates the performance of the system. However, this is compensated for by using a shorter operating period for the system across the day. Initially the system was expected to operate on average for 6.5 hours per day. However, tests have shown that the system actually operates closer to 8 hours per day. Solar radiation at the time of measurement is also shown in Fig. 4 as this largely influences the performance of the system.

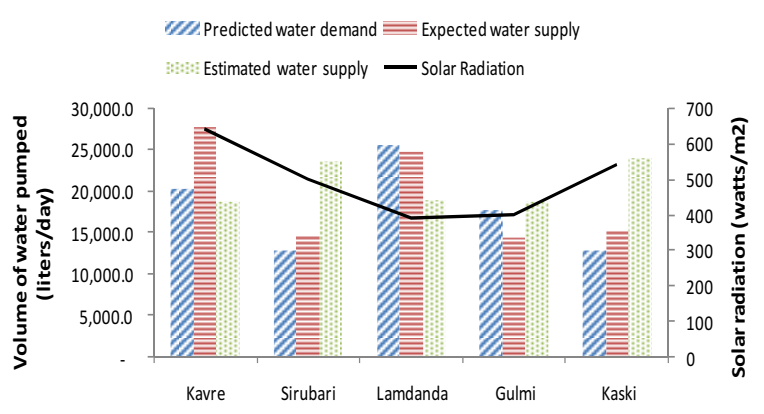

Fig. 4. Predicted water demand, expected and estimated pumped water supply and percentage solar radiation at the time of measurement 
Table $\mathrm{V}$ shows the estimated pumped water supply flow rate at three frequencies $(40 \mathrm{~Hz}, 45 \mathrm{~Hz}$ and $50 \mathrm{~Hz})$ for each of the installations. Lamdanda had the largest flow rate which also corresponded with the largest community and hence predicted demand for water. This site also corresponds with the shortest lift and transmission distance. Sirubari had the lowest estimated flow rate which corresponds to the site with the highest lift. Kavre, Gulmi and Kaski had approximately similar flow rates for each site.

TABLE V

INSTANTANEOUS PUMPED WATER FLOW RATES AT THREE FREQUENCIES FOR EACH INSTALLATION

\begin{tabular}{|c|c|c|c|}
\hline & \multicolumn{3}{|c|}{ Flow rate (litre/second) at pump frequency } \\
\hline & $\mathbf{4 0 H z}$ & $\mathbf{4 5 H z}$ & $\mathbf{5 0 H z}$ \\
\hline Kavre & 0.14 & 0.69 & 0.92 \\
\hline Sirubari & 0.06 & 0.42 & 0.78 \\
\hline Lamdanda & 0.2 & 0.60 & 1.06 \\
\hline Gulmi & 0.33 & 0.73 & 0.95 \\
\hline Kaski & 0.2 & 0.56 & 0.82 \\
\hline
\end{tabular}

Table VI shows the voltage and current at the control drive as well as the percentage solar radiation for each site when each measurement was taken. In all cases, with Kaski being the exception, solar PV configuration consisted of two strings of nine panels in parallel. In contrast, Kaski consisted of three strings of eight panels in parallel. The voltage was measured on the DC side of the controller and compared against that for Maximum Power Point (MPP) (after taking the number of solar panels in series and parallel into account) from Table IV. The voltage and current on the AC side of the controller was also recorded.

TABLE VI

ELECTRICAL CHARACTERISTICS FOR EACH SOLAR MUS INSTALLATION

\begin{tabular}{|c|c|c|c|c|c|}
\hline & $\begin{array}{c}\text { Radiation } \\
\text { level (\%) }\end{array}$ & $\begin{array}{c}\mathbf{V}_{\mathbf{D C}}- \\
\mathbf{M P P} \\
\mathbf{( V )}\end{array}$ & $\begin{array}{c}\mathbf{V}_{\mathbf{D C}}- \\
\text { measured } \\
(\mathbf{V})\end{array}$ & $\mathbf{V}_{\mathbf{A C}} \mathbf{( V )}$ & $\mathbf{I}_{\mathbf{A C}}(\mathbf{A})$ \\
\hline Kavre & $64 \%$ & 321.3 & 300 & 201 & 5.7 \\
\hline Sirubari & $50 \%$ & 275.4 & 273.4 & 210 & 6.9 \\
\hline Lamdanda & $39 \%$ & 275.4 & 270 & 209 & 5.2 \\
\hline Gulmi & $54 \%$ & 275.4 & 305 & 200 & 6.4 \\
\hline Kaski & $40 \%$ & 292 & 277 & 210 & 6.7 \\
\hline
\end{tabular}

Fig. 5 shows the estimated amount of daily pumped water by lift height. A linear trend line was added to show the influence of this parameter on the quantity of pumped water. From (1), one would expect the quantity of pumped water to decrease as the lift height increases, however, this is shown not to be the case. However, there are multiple factors at play that affect the amount of water that can be pumped such as: incident solar radiation, PV array size, transmission distance between source and community storage tanks, control unit and PV panels.

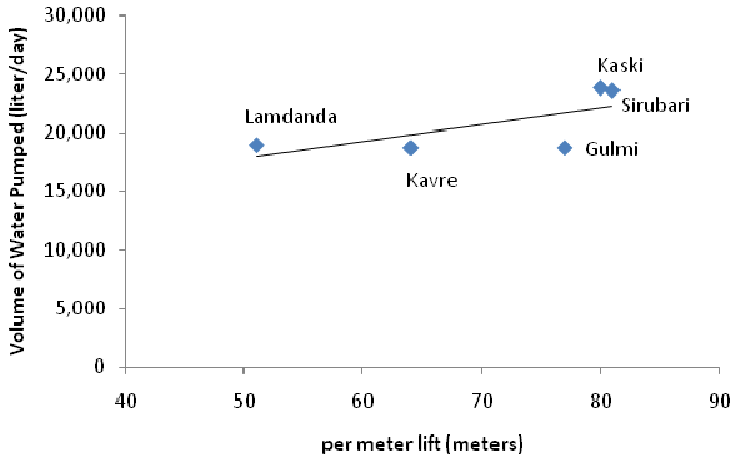

Fig. 5. Estimated daily pumped water by lift height for each installation

Fig. 6 shows the estimated volume of water pumped by transmission distance between source and community tanks. Similar to the last figure, an increase in pumped water was observed which is counter intuitive to (1).

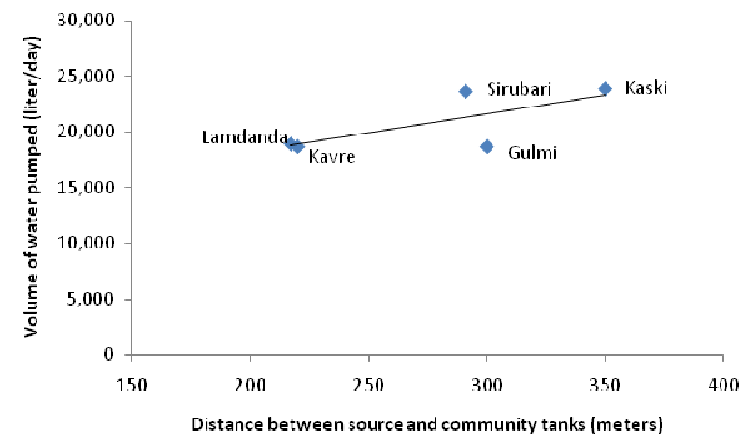

Fig. 6. Estimated daily pumped water by transmission distance between source and community tanks for each installation

Finally Fig. 7 shows the influence of distance between the solar PV panels and the control drive. Kaski and Sirubari performed well in this regard considering that both of these have relatively large water lifts and transmission distances compared to the other installations.

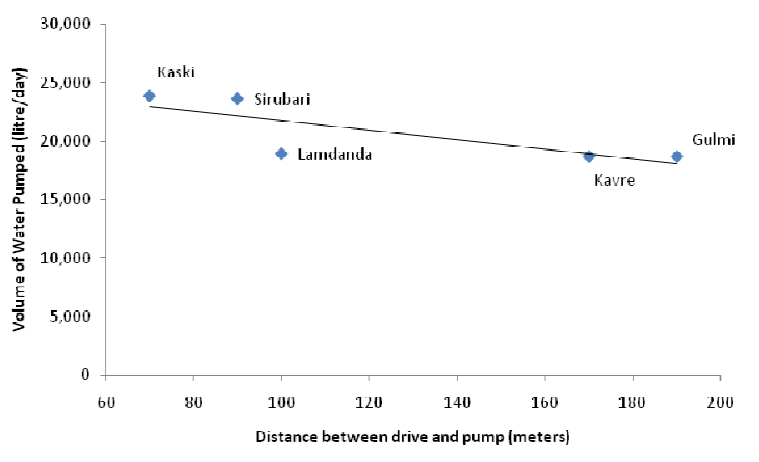

Fig 7. Estimated daily pumped water by distance between solar PV panels and control drive for each installation 
The total costs for the project are shown in Table VII (in US dollars) and broken down by the following categories:

" civil infrastructure - includes cement, pipes, pipe fittings, valves, tools and other construction materials;

" transportation - of any non-local materials. Note this does not include for the transportation of electrical infrastructure;

" skilled labor - for engineering design, supervision of construction;

» unskilled labor - for construction of all materials on site such as tanks, pipes and tap stands; and

" electrical infrastructure - PV system, pump, structure and installation

TABLE VII

TOTAL PROJECT COSTS IN US DOLLARS (\$) FOR EACH INSTALLATION BY CATEGORY

\begin{tabular}{|c|c|c|c|c|c|}
\hline & Kavre & Sirubari & Lamdanda & Gulmi & Kaski \\
\hline Civil & $3,616.13$ & $2,813.08$ & $1,692.38$ & $3,927.71$ & $1,201.77$ \\
\hline Transportation & 61.1 & 65.79 & 63.57 & 88.65 & 54.01 \\
\hline Skilled labor & 376.77 & 313.71 & 344.2 & 578.17 & 221.75 \\
\hline $\begin{array}{c}\text { Unskilled } \\
\text { labor }\end{array}$ & $5,624.71$ & $2,247.48$ & $1,283.38$ & $4,451.98$ & $1,987.07$ \\
\hline Electrical & $9,952.55$ & $13,015.86$ & $12,623.74$ & $15,422.25$ & $11,914.29$ \\
\hline Total & $19,631.26$ & $18,455.92$ & $16,007.26$ & $24,468.76$ & $15,378.90$ \\
\hline
\end{tabular}

Table VIII shows project costs for the following parameters: per installed Watt peak, per litre of estimated pumped water supply, cost per person and cost per metre lift.

TABLE VIII

PROJECT COSTS BY INSTALLED WATT PEAK $\left(\mathrm{W}_{\mathrm{P}}\right)$, ESTIMATED PUMPED WATER SUPPLY, COST PER PERSON AND PER METRE LIFT FOR EACH INSTALLATION

\begin{tabular}{|c|c|c|c|c|}
\hline & \multicolumn{4}{|c|}{ Costs } \\
\hline & $\mathbf{S} / \mathbf{W p}$ & $\begin{array}{c}\text { \$/litre } \\
\text { pumped }\end{array}$ & $\begin{array}{c}\text { \$/per } \\
\text { person }\end{array}$ & $\begin{array}{c}\text { \$/per metre } \\
\text { lift }\end{array}$ \\
\hline Kavre & 6.23 & 1.05 & 62.12 & 280.45 \\
\hline Sirubari & 4.10 & 0.78 & 92.74 & 227.85 \\
\hline Lamdanda & 3.56 & 0.84 & 36.38 & 313.87 \\
\hline Gulmi & 5.44 & 1.31 & 145.65 & 317.78 \\
\hline Kaski & 3.37 & 0.64 & 62.52 & 192.24 \\
\hline
\end{tabular}

\section{DISCUSSION}

Sirubari and Kaski had a similar estimated water pumping performances under comparable solar radiation conditions. Kavre, Lamdanda and Gulmi also had similar performances to each other in terms of the amount of water pumped. Measurements for Lamdanda and Gulmi were taken under similar low solar radiation conditions but the percentage radiation was much higher when the instantaneous flow rate was measured in Kavre. The difference in performance between Kavre, Lamdanda and Gulmi was expected due to the installation of a smaller PV array capacity in the former (3 $\mathrm{kWp})$ compared to the latter two sites $(4.5 \mathrm{kWp})$. Further monitoring of Kavre is advised in order to ascertain whether the system is fully achieving the desired water demand for the community. If adequate supply is not being met then replacement of the current $170 \mathrm{Wp}$ solar panels with that of the same rating as the other sites $(250 \mathrm{Wp})$ should resolve any shortfall in the amount of water being pumped.

The measured voltage on the DC side of the control drive at Kavre was 300 Volts. From Table IV the rated MPP for Kavre was 35.6 Volts and so the PV array on average was operating slightly below its optimum level at 33.34 Volts. Sirubari, Lamdanda and Gulmi all have a MPP voltage of 30.6 Volts. When measured, both Sirubari and Lamdanda operated close to this point on average with voltages of 30.38 Volts and 30.0 Volts respectively. In comparison, Gulmi operated much higher at 33.89 Volts which was unusually high and further investigation is required to ascertain why this was the case. Kaski's average operating voltage was measured at 34.63 Volts which was a little low when compared against its rated value of 36.5 Volts but still within acceptable limits.

The measured output voltage on the $\mathrm{AC}$ side of the control drive for each site was a little low considering the rated operation for the pump was between 220-230 Volts. However, this can be resolved by increasing the AC output voltage at the control drive. In addition this can also be done to offset any voltage drop in the cable connecting the control drive to the pump. The output current for each system was slightly less than expected for the incident solar radiation meaning that the pump was operating slightly below rated current.

Although it could not be fully quantified, harmonic distortion between PV panels and control drive appeared to have a significant impact on the performance of the system as a whole. Initial observations indicate that by keeping this distance under eighty metres will result in a better performing system. This was shown to be the case in Kaski and Sirubari, where short distances between PV panels and control drive appeared to result in a much better performing system even though high lifts and transmission distances were features of their design. Therefore the location of the solar panels relative to the source tank should be carefully considered during the design stage in order to minimize this distance.

As one would anticipate, incident solar radiation has a large bearing as to the amount of power produced and hence the overall performance of the system. The current produced by the solar PV array was slightly less than that required for optimum operation of the pump. However, as this can change significantly on a per minute basis it was difficult to ascertain 
the optimum size for the PV array without more detailed monitoring. However, the $4.5 \mathrm{~kW}$ array size appears to be a good choice in combination with the $1.5 \mathrm{~kW}$ pump and controller. In Gulmi, the array size should possibly be slightly larger in order to cater for the larger pump and control drive.

Project costs were largest for Gulmi on account of the large lift and transmission distance in combination with the high demand for water within the community. As a result, a greater amount of civil and electrical infrastructure had to be installed at this location. Gulmi had a relatively small community size, resulting in the installation being the most expensive on a per person, per litre of pumped water and per metre lift basis. On the other hand Kaski performed best in this regard being the least expensive installation on an installed Watt peak, per litre of pumped water and per metre lift basis.

\section{CONCLUSION}

The solar MUS system provides an alternative method for water pumping compared to the more traditional methods of using electricity and liquid fuels. The upfront capital costs can be high but this can be offset by having low operational costs and a relative long project lifespan. The civil infrastructure adds considerable costs to the project and therefore minimising this can result in a more cost effective solution overall. The autonomous operation means that the system can be left alone, with little intervention required from community members or a caretaker.

The solar MUS installations have proved to be useful for trialling the technology and comparing the performance of each system under different environmental, geographical and socio-economic conditions. Geographical parameters have a large bearing as to the overall performance of the system and hence heavily influence the initial design. Socio-economic variables have a large bearing as to the feasibility of projects, especially where communities want to finance their own projects in the future without donor funding.

\section{ACKNOWLEDGMENT}

The solar MUS project was financed through donor funding made available through Renewable World in partnership with iDE, community funding and various other small donors. Both Renewable World and iDE were also responsible for providing technical support, with iDE having responsibility for the implementation of the project.
Recognition for the complete electrical design for solar MUS goes to Sunco Systems while Sustainable Energy Nepal (SENEPAL) were responsible for the installation and commissioning of all electrical aspects to the project. SAPPROS were responsible for all civil infrastructure design and implementation.

\section{REFERENCES}

K. Branker, M. J. M. Pathak, and J. M. Pearce, "A review of solar photovoltaic levelized cost of electricity," Renewable and Sustainable Energy Reviews, vol. 15, no. 9, pp. 4470-4482, Dec. 2011.

[2] I. Odeh, Y. G. Yohanis, and B. Norton, "Economic viability of photovoltaic water pumping systems," Solar Energy, vol. 80, no. 7, pp. 850-860, Jul. 2006

M. Abu-Aligah, "Design of Photovoltaic Water Pumping System and Compare it with Diesel Powered Pump," Jordan Journal of Mechanical and Industrial Engineering, vol. 5, no. 3, pp. 273-280, 2011.

M. Al-Smairan, "Application of photovoltaic array for pumping water as an alternative to diesel engines in Jordan Badia, Tall Hassan station: Case study," Renewable and Sustainable Energy Reviews, vol. 16, no. 7, pp. 4500-4507, Sep. 2012.

[5] K. Meah, S. Ula, and S. Barrett, "Solar photovoltaic water pumping-opportunities and challenges," Renewable and Sustainable Energy Reviews, vol. 12, no. 4, pp. 1162-1175, May 2008. 